\title{
The Role of Hippocampal GluR1 and GluR2 Receptors in Manic-Like Behavior
}

\author{
Jing Du, ${ }^{1}$ Thomas K. Creson, ${ }^{1}$ Long-Jun Wu, ${ }^{2}$ Ming Ren, ${ }^{2}$ Neil A. Gray, ${ }^{1}$ Cynthia Falke, ${ }^{1}$ Yanling Wei, ${ }^{1}$ Yun Wang, ${ }^{1}$ \\ Rayah Blumenthal, ${ }^{1}$ Rodrigo Machado-Vieira, ${ }^{1}$ Peixiong Yuan, ${ }^{1}$ Guang Chen, ${ }^{1}$ Min Zhuo, ${ }^{2}$ and Husseini K. Manji ${ }^{1}$ \\ ${ }^{1}$ Laboratory of Molecular Pathophysiology, Mood and Anxiety Disorders Program, National Institute of Mental Health, National Institutes of Health, \\ Bethesda, Maryland 20878, and 2Department of Physiology, Faculty of Medicine, University of Toronto, Toronto, Ontario, Canada M5S 1A8
}

The cellular basis underlying the complex clinical symptomatology of bipolar disorder and the mechanisms underlying the actions of its effective treatments have not yet been fully elucidated. This study investigated the role of hippocampal synaptic AMPA receptors. We found that chronic administration of the antimanic agents lithium and valproate (VPA) reduced synaptic AMPA receptor GluR1/2 in hippocampal neurons in vitro and in vivo. Electrophysiological studies confirmed that the AMPA/NMDA ratio was reduced in CA1 regions of hippocampal slices from lithium-treated animals. Reduction in GluR1 phosphorylation at its cAMP-dependent protein kinase A site by the synthetic peptide TAT-S845, which mimics the effects of lithium or VPA, was sufficient to attenuate surface and synaptic GluR1/2 levels in hippocampal neurons in vitro and in vivo. Intrahippocampal infusion studies with the AMPA-specific inhibitor GYKI 52466 [4-(8-methyl-9H-1,3-dioxolo[4,5-h][2,3]benzodiazepin-5-yl)-benzenamine hydrochloride], a GluR1-specific TAT-S845 peptide, showed that GluR1/2 was essential for the development of manic/hedonic-like behaviors such as amphetamine-induced hyperactivity. These studies provide novel insights into the role of hippocampal GluR1/2 receptors in mediating facets of the manic syndrome and offer avenues for the development of novel therapeutics for these disorders.

Key words: lithium; valproate; AMPA; PKA; phosphorylation; manic-like behavior

\section{Introduction}

Bipolar disorder is a chronic, severe, often life-threatening illness (Goodwin and Jamison, 2007) that affects $\sim 1-2 \%$ of the U.S. population (Judd and Akiskal, 2003). Historically, the brain systems that have received the greatest attention in neurobiological studies of mood disorders were the monoaminergic neurotransmitter systems, which are extensively distributed throughout the network of limbic, striatal, hippocampal, and prefrontal cortical neuronal circuits and are thought to support the behavioral and visceral manifestations of mood disorders (Drevets, 2001; Manji et al., 2001; Nestler et al., 2002). Recently, however, a clear need for better treatments has been recognized, as has the lack of significant advances in our ability to develop novel, improved therapeutics for these devastating illnesses. This has led to the investigation of putative roles for intracellular signaling cascades and glutamatergically mediated synaptic plasticity in bipolar disorder (Coyle and Duman, 2003; Du et al., 2003a; Nestler and Carlezon, 2006; Young, 2007).

A growing body of data has linked the hippocampal region

Received July 6, 2007; revised 0ct. 15, 2007; accepted Nov. 2, 2007.

This work was supported by the Intramural Research Program of the National Institute of Mental Health and by the Stanley Medical Research Institute. M.Z. was supported by the ELL-Canadian Institutes of Health Research Michael Smith Chair in Neurosciences and Mental Health and the Canada Research Chair. We thank Drs. Yutian Wang and Todd Gould for critical scientific reading and loline Henter for outstanding editorial assistance.

Correspondence should be addressed to Dr. Husseini K. Manji, Laboratory of Molecular Pathophysiology, Mood and Anxiety Disorders Program, National Institute of Mental Health, 9000 Rockville Pike, Building 35, 1C912, Bethesda, MD 20892. E-mail: manji@nih.gov.

DOI:10.1523/JNEUROSCI.3080-07.2008

Copyright $\odot 2008$ Society for Neuroscience $\quad$ 0270-6474/08/280068-12\$15.00/0 and bipolar disorder (for review, see Goodwin and Jamison, 2007). In the adult hippocampus (Loza et al., 2005; Liu et al., 2007), the AMPA receptor population comprises primarily glutamate receptor 1 (GluR1)/GluR2 and GluR2/GluR3 heteromers (Wenthold et al., 1996). A number of studies indicate that the synaptic delivery of different subunit combinations is governed by molecular rules encoded in the intracellular $\mathrm{C}$ terminals of the receptor subunits (Malinow, 2003). Phosphorylation of serines 831 and 845 (S831 and S845) in the GluR1 subunit by calcium/ calmodulin-dependent protein kinase II (CaMKII) and cAMPdependent protein kinase (PKA), respectively, regulates the ion channel properties and synaptic trafficking of GluR1-containing AMPA receptors during hippocampal long-term potentiation (LTP) (Roche et al., 1996; Barria et al., 1997; Mammen et al., 1997; Derkach et al., 1999; Banke et al., 2000; Lee et al., 2000; Esteban et al., 2003). Dephosphorylation of the GluR1 subunit at its PKA site by protein phosphatases (e.g., calcineurin and protein phosphatase 1) targets GluR1 for recycling endosomes during long-term depression (Banke et al., 2000).

Because AMPA receptor trafficking is critical for regulating various forms of synaptic plasticity in the CNS, its potential involvement in the pathophysiology or treatment of certain neuropsychiatric disorders is an emerging area of interest (Snyder et al., 2000; Carlezon and Nestler, 2002; Chao et al., 2002; Self, 2002; Brebner et al., 2005; Peineau et al., 2007). Notably, two antimanic agents that are structurally highly dissimilar, lithium and valproate (VPA), when administered in therapeutically relevant doses, exert major effects on intracellular signaling cascades 
known to regulate AMPA receptor trafficking (Coyle and Duman, 2003; Du et al., 2003b). We therefore postulate that the effects of antimanic agents may ultimately converge to regulate AMPA receptor trafficking in critical neuronal circuits that mediate cardinal symptoms of the manic syndrome (e.g., excessive motoric and hedonic activity). Because GluR1/2 heterodimers are known to regulate various forms of synaptic plasticity, we undertook this series of studies to investigate the effects of lithium or VPA on AMPA receptor GluR1/2 distribution at synapses in vivo and in vitro. The functional significance of synaptic GluR1/2 was further addressed in animal models of manic-like behaviors.

\section{Materials and Methods Animal drug treatment}

All animal treatments, procedures, and care were approved by the $\mathrm{Na}-$ tional Institute of Mental Health (NIMH) Animal Care and Use Committee and followed the Guide for the Care and Use of Laboratory Animals (ISBN 0-309-05377-3). Male Wistar Kyoto rats (7-8 weeks; starting weight, 150-200 g; Harlan, Indianapolis, IN) were housed three to four per cage in a $12 \mathrm{~h}$ light/dark cycle and had ad libitum access to water and food. After a 1 week accommodation period, the rats were treated with lithium or VPA. Lithium- or VPA-containing chow was custom produced by Bio-Serve (Frenchtown, NJ). Drug-containing chow and control chow were identical, with the exception of the added drug, and were produced at both a low and regular concentration for each drug with concentrations of lithium carbonate at 1.2 and $2.4 \mathrm{~g} / \mathrm{kg}$, respectively, and sodium VPA at 10 and $20 \mathrm{~g} / \mathrm{kg}$, respectively. These doses of lithium or VPA have been used extensively by our group and others and have been found to lead to serum drug levels similar to those achieved therapeutically in the treatment of bipolar disorder (Yuan et al., 1999). Rats were initially treated for 1 week at the lower dose (to acclimatize them to the diet and reduce risks of side effects), followed by 3 weeks of the higherdose treatment. The lithium experiment included 12 control and 12 experimental animals, all provided with an extra bottle of saline and daily bedding changes to minimize the effects of lithium-induced polyuria (a well known side effect of lithium). The VPA experiment also included 12 control and 12 experimental animals. An additional group of imipramine-treated animals was given injections of imipramine (10 $\mathrm{mg} / \mathrm{kg}$ in $0.3 \mathrm{ml}$ of saline) or saline (twice daily, i.p.) for 4 weeks.

For the electrophysiology studies, both control- and lithium-treated male rats were maintained at University of Toronto animal facilities. The animals were treated with lithium as described previously, beginning at 4 weeks of age. Experiments were performed at 8-9 weeks of age. The experimental protocol used in this study was approved by The Animal Studies Committee at the University of Toronto.

All rats were weighed and then killed by decapitation during the morning hours. Trunk blood was collected for analysis of drug levels. Mean and SD for the weights of the animals used for the biochemical studies were as follows: control, $310.42 \pm 16.83$; lithium, $287.18 \pm 17.80$; VPA, $244.33 \pm 11.93$ g. Drug serum levels were performed by Medtox Laboratories (St. Paul, MN). Only animals with drug levels within the therapeutic range were used for additional studies. In general, $\sim 80 \%$ of animals achieved therapeutic levels. Serum blood levels of the animals used for additional analyses were as follows: lithium, $0.80 \pm 0.13 \mathrm{mEq} / \mathrm{L} ; \mathrm{VPA}$, $80.6+8.8 \mu \mathrm{g} / \mathrm{ml}$. Hippocampal tissue was dissected immediately after decapitation. Brain specimens were frozen rapidly in liquid nitrogen and stored at $-80^{\circ} \mathrm{C}$ until further analysis.

\section{Synaptosomal preparation and Western blot analysis}

Both hippocampi from each animal were obtained to prepare synaptosomes using the differential and discontinuous Ficoll gradient centrifugation method (Pozzo-Miller et al., 1999). Briefly, hippocampal tissue was homogenized in $3 \mathrm{ml}$ of cold Syn buffer ( $300 \mathrm{~mm}$ mannitol and $1 \mathrm{~mm}$ EDTA, $\mathrm{pH}$ 7.4). Aliquots of the crude homogenate were used to determine levels of synaptic proteins in the whole hippocampus. The remaining homogenates were centrifuged at $5000 \times g$ for $10 \mathrm{~min}$. The supernatants were centrifuged at $15,000 \times g$ for $30 \mathrm{~min}$. The pellets were then resuspended in Syn buffer, loaded on Ficoll gradient tubes, and centrifuged at 22,000 $\times g$ at $4^{\circ} \mathrm{C}$ for $90 \mathrm{~min}$. Proteins in the interfaces between 8 and $12 \%$ and between 12 and 16\% Ficoll gradient were collected, diluted in Syn buffer in a ratio of 1:4, and centrifuged for $20 \mathrm{~min}$ at $15,000 \times g$. Pellets were resuspended in $500 \mu \mathrm{l}$ of $1 \times \mathrm{P}$ buffer $[5.4 \mathrm{~mm}$ $\mathrm{KCl}, 0.8 \mathrm{~mm} \mathrm{MgSO}_{4}, 5.5 \mathrm{~mm}$ glucose, $50 \mathrm{~mm}$ HEPES, $130 \mathrm{~mm}$ choline chloride, $1 \mathrm{~mm}$ bovine serum albumin (BSA), and 0.01\% CHAPS (3- [(3cholamidopropyl)dimethylammonio]-1-propanesulfonate)]. Protein concentration was determined using the BCA assay (Pierce, Rockford, IL); the presence of mannitol in the crude homogenates did not significantly affect the linearity of this assay. Equal amounts of protein from either homogenized hippocampus ( $3 \mu \mathrm{g}$ ) or hippocampal synaptosomes (1-3 $\mu \mathrm{g}$ ) were separated by $10 \%$ SDS gradient gel electrophoresis (Invitrogen, Carlsbad, CA), transferred to $0.45 \mu \mathrm{m}$ pore-size polyvinylidene difluoride (PVDF) membranes (Millipore, Bedford, MA), and immunoblotted with anti-GluR2 (1:2000) and anti-GluR3 (1:200) antibodies (Chemicon, Temecula, CA). Horseradish peroxidase-conjugated antirabbit antibody (Amersham Biosciences, Piscataway, NJ; and Vector Laboratories, Burlingame, CA) was used as a secondary antibody. Immunoreactive bands were visualized by enhanced chemiluminescence (ECL+; Amersham Biosciences ) and exposed to Kodak (Rochester, NY) Biomax or Biolight film. The ECL signal intensities were quantified using a Kodak Image system based on standard curves of these synaptic proteins. All data were analyzed by Student's $t$ test and presented as means \pm SEM.

\section{Immunoprecipitation}

Total protein $(2 \mu \mathrm{g})$ from synaptosomal preparation was mixed with equal-amount $2 \times$ lysis buffer [100 mм Tris- $\mathrm{HCl}, \mathrm{pH} 7.5,0.1 \%(\mathrm{v} / \mathrm{v})$ Triton X-100, $300 \mathrm{~mm} \mathrm{NaCl}, 5 \mathrm{~mm}$ EDTA, $0.02 \%$ sodium azide, $2 \mu \mathrm{g} / \mathrm{ml}$ apoptinin, $2 \mu \mathrm{g} / \mathrm{ml}$ leupeptin, and $1 \mathrm{~mm}$ PMSF] for $30 \mathrm{~min}$ at $4^{\circ} \mathrm{C}$. After centrifugation for $1 \mathrm{~h}$ at $100,000 \times \mathrm{g}$, the sample $(2 \mu \mathrm{g})$ was preincubated with $50 \mu \mathrm{l}$ of protein G-Sepharose slurry (Amersham Biosciences) and rotated at $4^{\circ} \mathrm{C}$ for $1 \mathrm{~h}$. The precleared protein was incubated with either 2 $\mu \mathrm{g}$ of anti-GluR2 antibody (Chemicon) for $4 \mathrm{~h}$ at $4^{\circ} \mathrm{C}$ before the addition of $50 \mu$ l of protein G-Sepharose slurry. After mixing at $4^{\circ} \mathrm{C}$ overnight, the sample was centrifuged, and the supernatant ("unbound fraction") was collected and mixed with $50 \mu \mathrm{l}$ of protein G-Sepharose slurry for $4 \mathrm{~h}$ at $4^{\circ} \mathrm{C}$. The beads were then washed three times in ice-cold lysis buffer and resuspended in an adjusted volume of protein sample buffer. Fractions were then boiled, separated by $4-15 \%$ gradient SDS-PAGE, and transblotted to PVDF membranes for immunodetection of GluR1 with antiGluR1 antibody (Chemicon).

\section{Whole-cell patch-clamp recordings}

Adult male rats were anesthetized with 1-2\% halothane and decapitated. Coronal slices of the hippocampus $(300 \mu \mathrm{m})$ were prepared using methods routinely used in our laboratory (Wu et al., 2007). Slices were transferred to a submerged recovery chamber with oxygenated $\left(95 \% \mathrm{O}_{2}\right.$ and $5 \% \mathrm{CO}_{2}$ ) artificial CFS (aCSF) containing (in mM) $124 \mathrm{NaCl}, 2.5 \mathrm{KCl}, 2$ $\mathrm{CaCl}_{2}, 2 \mathrm{MgSO}_{4}, 25 \mathrm{NaHCO}_{3}, 1 \mathrm{NaH}_{2} \mathrm{PO}_{4}$, and 10 glucose at room temperature for at least $1 \mathrm{~h}$.

Experiments were performed in a recording chamber on the stage of an Olympus (Tokyo, Japan) BX51WI microscope with infrared differential interference contrast optics for visualization of whole-cell patchclamp recordings. In the presence of picrotoxin $(100 \mu \mathrm{M})$, which blocked $\mathrm{GABA}_{\mathrm{A}}$ receptors, EPSCs were recorded from hippocampal CA1 pyramidal neurons with a Molecular Devices (Palo Alto, CA) 200B amplifier, and the stimulations were delivered by a bipolar tungsten stimulating electrode placed in striatum radium. EPSCs were induced by repetitive stimulations at $0.02 \mathrm{~Hz}$, and neurons were voltage clamped at $-70 \mathrm{mV}$ to determine AMPA receptor-mediated EPSCs. The recording pipettes (3-5 $\mathrm{M} \Omega$ ) were filled with a solution containing (in mM) $145 \mathrm{CsMeSO}_{3}, 5$ $\mathrm{NaCl}, 1 \mathrm{MgCl}_{2}, 0.2$ EGTA, 10 HEPES, $2 \mathrm{Mg}$-ATP, $0.1 \mathrm{Na}_{3}$-GTP, and 5 QX-314 [N-(2,6-dimethylphenylcarbamoylmethyl)-triethylammonium bromide], adjusted to $\mathrm{pH} 7.2$ with $\mathrm{CsOH}$. An NMDA receptor-mediated EPSC was tested as current amplitude at $50 \mathrm{~ms}$ after peak EPSC amplitude at a holding potential of $+40 \mathrm{mV}$. The ratios of AMPA and NMDA EPSCs were calculated, and data were analyzed by Student's $t$ test. 


\section{Hippocampal neuronal culture preparations}

Cultures of hippocampal neurons were prepared as described previously (Du et al., 2000) with minor modifications. Briefly, whole hippocampi were dissected from embryonic day 18 (E18) Sprague Dawley rats, dissociated in $\mathrm{Ca}^{2+}$ - and $\mathrm{Mg}^{2+}$-free HBSS containing $0.125 \%$ trypsin for 15 min, triturated in DMEM (Invitrogen) $/ 10 \%$ fetal bovine serum, and plated at 0.4 million cells per well in six-well plates. Cells were grown at $37^{\circ} \mathrm{C}, 5 \% \mathrm{CO}_{2}$, and $95 \%$ humidity, first in $10 \%$ fetal bovine serum/ DMEM followed $1 \mathrm{~d}$ later with serum-free medium, Neurobasal plus B27 (B27NB; Invitrogen). Cultures were grown in serum-free medium for $8-10 \mathrm{~d}$ before the start of the experiments, and the medium was changed every $3 \mathrm{~d}$. Fresh medium was applied $24 \mathrm{~h}$ before each experiment. These cultures yielded virtually all neurons.

\section{Peptide treatment in vitro and in vivo}

Peptides designed to block the phosphorylation of GluR1 at the PKA site (S845) were synthesized in conjunction with a TAT sequence, which is a human immunodeficieny virus (HIV) sequence capable of delivering peptides into the brain passing the blood-brain barrier (Celtek Bioscience, Nashville, TN). A scrambled TAT-SCR sequence containing the same amino acids as that of the TAT-S845-specific sequence fused to the same TAT peptide sequence served as a TAT control. The sequence of TAT-S845 was YGRKKRRQRRRTLPRNSGAG, and its scrambled control (TAT-SCR) was YGRKKRRQRRRSTGLAPGRN. The concentration of the peptides used for in vitro studies was $80 \mu \mathrm{M}$ in B27NB medium.

C57BL/6 J mice were obtained from a breeding colony (Taconic, Germantown, NY). Animals were group housed ( $n=4$ per cage) in polypropylene cages on a $12 \mathrm{~h}$ light/dark cycle at $25^{\circ} \mathrm{C}$ and had ad libitum access to water and chow. Synthesized peptide ( $1-5 \mathrm{mg} / 25 \mathrm{~g}$ mice/d) was dissolved in $0.25 \mathrm{ml}$ of saline and injected (intraperitoneally) into the animals for 1-4 d. Hippocampal tissue was then collected, and synaptosomal fractions were prepared as described previously. Phosphorylation of GluR1 at S845 was determined by Western blot analysis with total homogenate. The GluR1 or GluR2, or NR1 (NR1 antibody; Chemicon), contents in the synaptosomal preparations from hippocampi of the peptide-treated mice were also determined by Western blot analysis.

\section{Surface biotinylation and Western blot analysis of GluR1, GluR2, and GluR3}

Surface GluR2 receptors were detected by biotinylation assay followed by Western blot analysis using either a GluR2 antibody or a N-cadherin antibody (Sigma, St. Louis, MO) as described. At the end of VPA, lithium, or peptide treatment, for the times indicated, ice-cold PBS (with calcium and magnesium, $\mathrm{pH}$ 7.4; Invitrogen) was added to the cultures to prevent receptor internalization. After three washes with ice-cold PBS, cells were incubated in Sulfo-NHS-LC-biotin $(0.25 \mathrm{mg} / \mathrm{ml}$ in cold PBS; Pierce) for $30 \mathrm{~min}$. The surface biotinylation was stopped by removing the above solution and incubating with $10 \mathrm{~mm}$ ice-cold glycine in PBS for $20 \mathrm{~min}$. Cells were then washed three times with cold PBS and lysed with radioimmunoprecipitation assay (RIPA) buffer [20 mM HEPES, pH 7.4, $100 \mathrm{~mm} \mathrm{NaCl}, 1 \mathrm{~mm}$ EGTA, $1 \mathrm{~mm} \mathrm{Na}$ orthovanadate, $50 \mathrm{~mm} \mathrm{NaF}, 1 \%$ NP-40, $1 \%$ deoxycholate, $0.1 \%$ SDS plus Protease Inhibitor Cocktail (Sigma), and Phosphatase Inhibitor Cocktails I\&II (Sigma)]. Equal amounts of biotinylated proteins were precipitated with $100 \mu \mathrm{l} \mathrm{of} \mathrm{Im-}$ munoPure Immobilized Streptavidin (Pierce). Biotinylated proteins were separated on a $10 \%$ SDS-PAGE gel and transferred to a nitrocellulose membrane. The membranes were probed with a polyclonal antiGluR2 antibody (1:200; Chemicon), stripped, and reprobed with anti-Ncadherin antibody (1:200; Chemicon), followed by peroxidaseconjugated goat anti-rabbit IgG (1:3000; Vector Laboratories). Immunoreactive bands were visualized by ECL (Amersham Biosciences). The ECL signal intensities were quantified by the Kodak Image program.

\section{Fluorescent double immunostaining}

Rat hippocampal neurons were treated with lithium (1.0 mM) or VPA $(1.0 \mathrm{~mm}$ ) for $4 \mathrm{~d}$ and fixed in $4 \%$ paraformaldehyde in PBS for $1 \mathrm{~h}$ on ice. The cells were then blocked with $10 \%$ normal goat serum, $1 \%$ BSA, and $0.4 \%$ Triton X-100 in PBS for $1 \mathrm{~h}$. After incubating in rabbit anti-GluR2 (1:40; Chemicon) and mouse anti-Synapsin I (1:100; Chemicon) at $4^{\circ} \mathrm{C}$ overnight, the cells were washed extensively in PBS. The secondary anti- bodies were FITC-conjugated anti-mouse (for multiple staining; 1:50; Jackson ImmunoResearch, West Grove, PA) and Cy3-conjugated antirabbit (for multiple staining; 1:150; Jackson ImmunoResearch) antibodies. After extensive washing, the cells were mounted onto slides with anti-fade mounting medium (Invitrogen, Eugene, OR). Z-stack imaging was acquired by using a Zeiss (Thornwood, NY) 510-Meta confocal microscope under exactly the same conditions as the controls. Neurons were randomly photographed with five images obtained for each slice to ensure that conditions for each slice for each group were the same. The longest dendrite from each neuron treated in each group was chosen for quantification. Average dendrite lengths did not differ significantly among the control-, lithium-, or VPA-treated groups. Fluorescent intensities of GluR1 (red) and synaptotagmin (green) at each individual synapse on the longest dendrite were calculated using 510-Meta software. Data were analyzed by one-way ANOVA.

\section{Behavioral tests}

Peptides. TAT-S845 and TAT-SCR control peptides were dissolved in an aCSF solution (Alzet, Cupertino, CA) at a concentration of $160 \mu \mathrm{M}$. 4-(8-Methyl-9H-1,3-dioxolo[4,5-h][2,3] benzodiazepin-5-yl)-benzenamine hydrochloride (GYKI 52466; $50 \mu \mathrm{M}$ ), a selective AMPA receptor antagonist, was obtained from Tocris (Ellisville, MO).

Animals and animal treatments. All animal experiments were approved by the NIMH Animal Care and Use Committee in accordance with National Institutes of Health guidelines on the care and use of animals. Male Sprague Dawley rats (250-300 g) were obtained from Charles River Laboratories (Wilmington, MA) and allowed a 1 week period of acclimatization to the environment before experiments began. All rats were housed two per cage with ad libitum access to water and food and maintained under a $12 \mathrm{~h}$ light/dark cycle. For the behavioral tests, rats were housed individually.

Intrahippocampal surgery. Instruments used to perform stereotaxic surgeries were equipped with a gas anesthesia mask (David Kopf Instruments, Tujunga, CA) for delivery of isoflurane at a flow rate of $5 \mathrm{lpm}$ for anesthetic induction and $2 \mathrm{lpm}$ for maintenance. Osmotic minipumps (model 1002; flow rate, $0.25 \mu \mathrm{l} / \mathrm{h}$; Alzet/Durect Corporation, Cupertino, CA) filled with GYKI 52466 or aCSF or with TATS845, TAT-SCR, or aCSF were attached to brain infusion kits (BIK Model I; Alzet/Durect Corporation) with polyethylene tubing. BIK cannulas were guided to the dentate gyrus (anteroposterior, $-3.8 \mathrm{~mm}$; mediolateral, $\pm 2.0 \mathrm{~mm}$; dorsoventral, $-3.6 \mathrm{~mm}$ ), and the pumps were implanted subcutaneously between the scapulae. One day after the conclusion of the behavioral studies, rats were prepared for induction of deep anesthesia with chloral hydrate $(400-450 \mathrm{mg} / \mathrm{kg}$, i.p.) and perfused with normal saline followed by $4 \%$ paraformaldehyde to preserve brain tissue (for fixed tissue preparation for immunostaining).

Open-field test and amphetamine hyperactivity test. For the open-field test, each rat was placed in the center of an activity chamber $(43 \times 43 \mathrm{~cm}$; Opto-Varimex; Columbus Instruments, Columbus, $\mathrm{OH}$ ), and total activity was recorded over a $60 \mathrm{~min}$ period. For the amphetamine hyperactivity tests, rats were placed in the center of an activity box for $30 \mathrm{~min}$, followed immediately by an intraperitoneal $1 \mathrm{mg} / \mathrm{kg}$ injection of amphetamine. There was a $5 \mathrm{~min}$ waiting period to accommodate for any stressrelated fluctuations in activity caused by the injection, after which activity was recorded for another $30 \mathrm{~min}$ period.

\section{Immunohistochemistry}

All animals were anesthetized with chloral hydrate $(400-450 \mathrm{mg} / \mathrm{kg}$, i.p.) and perfused transcardially with $0.1 \mathrm{~m}$ PBS, $\mathrm{pH} 7.4$, followed by $4 \%$ paraformaldehyde in $0.1 \mathrm{M}$ PBS, $\mathrm{pH}$ 7.4. Brains were removed, postfixed in the same fixative for $6 \mathrm{~h}$, and cryoprotected by infiltration with $30 \%$ sucrose for an additional $36 \mathrm{~h}$. Thereafter, the brain tissues were frozen and sectioned with a cryostat at $20 \mu \mathrm{m}$, and sections were mounted to glass slides.

To obtain comparable immunohistochemical data, tissue sections of both control and experimental animals were simultaneously processed on the same day. The sections were sequentially treated with $0.3 \%$ hydrogen peroxide $\left(\mathrm{H}_{2} \mathrm{O}_{2}\right)$ in PBS for 30 min and $10 \%$ normal horse serum in $0.05 \mathrm{~m}$ PBS for $30 \mathrm{~min}$. The sections were next incubated with diluted 
mouse anti-phospho-GluR1S845 (1:1000) for $48 \mathrm{~h}$ at $4^{\circ} \mathrm{C}$. Thereafter, the tissues were exposed to biotinylated goat anti-rabbit IgG and streptavidin peroxidase complex (Vector Laboratories). The sections were visualized with 3,3' -diaminobenzidine in $0.1 \mathrm{M}$ Tris buffer and mounted with coverslips at the same time. For quantification of the positive cell numbers in each brain region, four sets of animals infused with TAT-S845 or TATSCR peptide were processed for immunostaining ( $n=4$ in each group). The sections with the cannula insertion of each animal were immunostained with anti-phospho-GluR1 antibody under exactly the same conditions. We counted the phospho-GluR1 S845-positive cells in three fields of CA1 and dentate gyrus cell layers adjacent to the cannula insertion. Each field contains $70-150$ cells. We also randomly took pictures of three fields from the CA3 region. Each field of the CA3 region contains 40-80 neurons. The percentage of phospho-GluR1S845-positive cells was determined. Data were analyzed by Student's $t$ test.

\section{Results}

The structurally dissimilar antimanic agents lithium and VPA attenuate AMPA receptor subunit GluR1 and GluR2 synaptic expression in vivo

We undertook this series of studies to investigate GluR2 synaptic localization after treatment with lithium or VPA and their interactions with GluR1 receptors. Rats were treated chronically with lithium or VPA for 4 weeks. Hippocampal synaptosomal fractions, containing both presynaptic and postsynaptic nerve terminals, were prepared using the discontinuous Ficoll gradient method. To ensure the clinical relevance of these results, serum concentrations of both lithium and VPA were determined from blood samples collected at the time animals were killed. Only samples with concentrations that fell within respective therapeutic ranges (0.5-1.2 mM for lithium and $50-125 \mu \mathrm{g} / \mathrm{ml}$ for VPA) were used for additional analysis.

Because GluR1 and GluR2 receptors form tetramers in hippocampus, we sought to determine the effects of the treatments on synaptic localization of GluR1/2. Coimmunoprecipitation experiments were performed to determine the association of GluR1 and GluR2 at the synapses. Immunoprecipitation with antiGluR2 antibody coprecipitated with GluR1 in synaptosomal samples prepared from hippocampus (Fig. 1A). Using a specific protein/antibody ratio, more than $\sim 60 \%$ of GluR 1 was recovered by coprecipitation with GluR2 from the total synaptic protein, suggesting that the majority of GluR1 receptors form tetramers with GluR2 at synapses (Fig. 1A). To confirm the specificity of the immunoprecipitation with GluR2 antibody, rabbit antiinsulin-like growth factor 1 (IGF-1) antibody was used as an antibody control. Coprecipitation with anti-IGF-1 antibody or without antibody did not result in any GluR1 coprecipitation (Fig. 1A).

Within the AMPA receptor complex, GluR2 forms heterotetramers with both GluR1 and GluR3 receptors, and GluR1/2 and GluR2/3 are the major forms of AMPA receptor tetramers in hippocampus. A decrease in the GluR1 subunit level at synapses has been shown previously in the same paradigm ( $\mathrm{Du}$ et al., 2004). Therefore, we examined GluR2 and GluR3 levels in synaptosomal fractions from hippocampal tissue by Western blot analysis. GluR2 expression from the preparation was significantly attenuated in lithium- and VPA-treated rats by $\sim 34$ and $25 \%$, respectively (Fig. $1 B$ ) (one-way ANOVA, $p<0.05$ ). Western blot analysis of synaptosomal preparations from hippocampi of lithium- or VPA-treated animals showed that GluR3 levels were no different from that of controls (Fig. 1C). PSD95 (postsynaptic density-95) and synaptophysin, used as protein loading controls, were unchanged among the three treatment groups (data not shown). GluR1 levels (as a postsynaptic marker) were enriched
A.
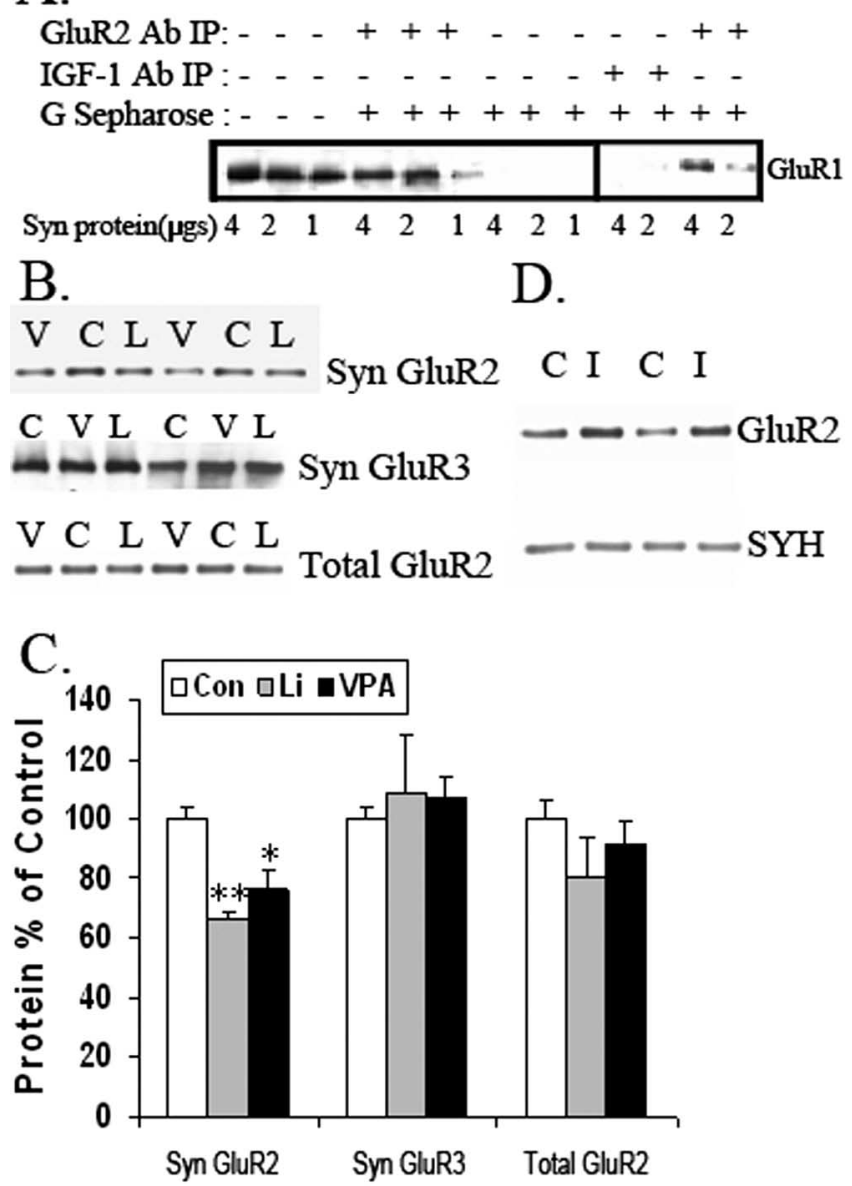

Figure 1. AMPA receptor subunit GluR2 is attenuated in synaptosomal preparation from long-term lithium- and VPA-treated animals. $A$, Coimmunoprecipitation of GluR1 and GluR2 in rat synaptosomal preparation. Different amounts of synaptosomal (Syn) proteins were immunoprecipitated with the anti-GluR2 antibody. Anti-IGF antibodies were used as a negative control. Western blot analysis was performed to determine whether GluR1 coprecipitates with GluR2. Ab, Antibody; IP, immunoprecipitation. B, C, Western blot analysis of synaptic (Syn) GluR2 and GluR3 and total GluR2 content in the hippocampus from lithium (L, Li)-treated and VPA (V)-treated animals and control ( $C, C o n)$ animals $(n=6-8$ animals per group; one-way ANOVA, $p=0.0021$; Con vs Li, ${ }^{* *} p<0.01$; Con vs VPA, ${ }^{*} p<0.05$ ). Error bars indicate SE. $\boldsymbol{D}$, The antidepressant imipramine (I) increased synaptic GluR2 in vivo. Rats were treated with imipramine for $10 \mathrm{~d}$. The synaptosomal proteins from hippocampal tissue were analyzed with anti-GluR2 antibody ( $n=8$; one-way ANOVA, $p=0.1485$ ). Synaptophysin (SYH) was used as a loading control. C, Control.

four times compared with a pooled tissue homogenate from control animals (data not shown).

To determine whether the reduction in synaptic GluR2 levels was attributable to a reduction in the total levels of GluR2 receptors, Western blot analysis of GluR2 levels in hippocampal homogenates from chronically treated rats was undertaken. There was no significant decrease in GluR2 levels after lithium treatment or VPA treatment by one-way ANOVA, suggesting that the reductions in synaptic GluR2 levels were not attributable to a reduction in overall GluR2 expression but might involve GluR2 receptor trafficking (Fig. 1C). This was examined in cultured hippocampal neurons.

Because we wanted to assess whether this effect is specific to mood stabilizers, we also tested the in vivo effect of the antidepressant imipramine on AMPA receptor localization at the synapses. We found that imipramine, which can provoke mania in humans (Prien 
A

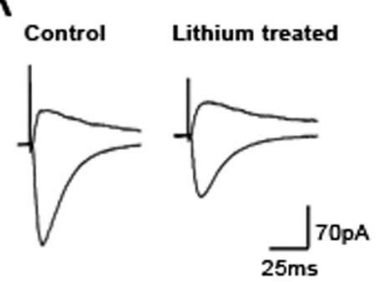

B
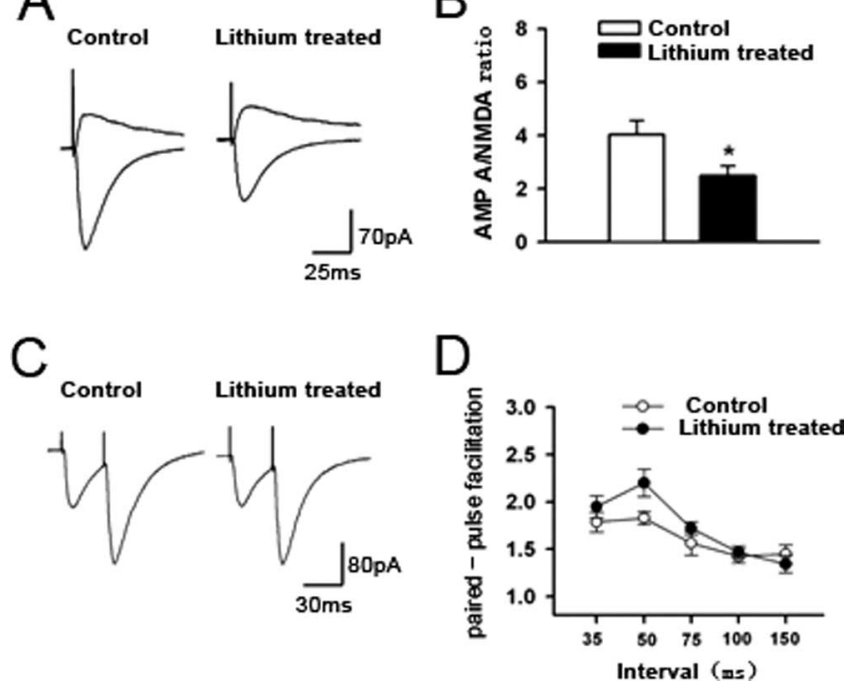

Figure 2. Chronic lithium treatment reduces the AMPA/NMDA ratio in hippocampal CA1 neurons. Electrophysiological studies were performed to determine the AMPA/NMDA ratio and PPF in the CA1 region of hippocampal slices from the chronically lithium-treated animals. $A$, Sample traces of the AMPA/NMDA ratio in the CA1 region of hippocampal slices from lithiumtreated and control animals. $\boldsymbol{B}$, Significant reduction in the AMPA/NMDA ratio in lithiumtreated rats $(n=8)$ compared with control rats $(n=10)\left({ }^{*} p=0.024\right.$, unpaired Student's $t$ test). $C$, Representative traces of PPF in the CA1 region of hippocampal slices from control and lithium-treated animals ( $35 \mathrm{~ms}$ ). D, PPF of the CA1 region from lithium-treated hippocampal slices. There was no difference in PPF between control $(n=11)$ and lithium-treated $(n=9)$ rats. Error bars indicate SE.

et al., 1973, 1984), significantly enhanced GluR2 at synapses in hippocampus (control: $100 \pm 11.2 \%, n=7$; imipramine: $131.6 \pm$ 7.23\%, $n=8$; Student's $t$ test, $p=0.033$ ) (Fig. 1D).

Chronic lithium treatment reduces the AMPA/NMDA ratio in hippocampal CA1 neurons

To confirm the functional significance of the effects of lithium on GluR1/GluR2 synaptic localization as described above, electrophysiological studies were performed in animals chronically treated with lithium. To determine whether lithium treatment altered the function of AMPA, but not NMDA, receptors, the AMPA/NMDA ratio was examined in hippocampal CA1 pyramidal neurons from control and lithiumtreated rats. This ratio was calculated by the AMPA receptormediated EPSC (the peak amplitude of the EPSC at a holding potential of $-70 \mathrm{mV})$ divided by the NMDA receptormediated EPSC (current amplitude at $50 \mathrm{~ms}$ after peak EPSC amplitude at a holding potential of $+40 \mathrm{mV}$ ). In the control rats, the AMPA/NMDA ratio was $4.0 \pm 0.5(n=10)$ (Fig. $2 A, B)$. However, the ratio was significantly reduced in lithium-treated rats $(2.5 \pm 0.4 ; n=8$; Student's $t$ test, $p<$ $0.05)$ (Fig. $2 B$ ). To test whether lithium treatment affects presynaptic glutamate release, we conducted paired stimulation protocols. Two stimuli were delivered with an interval ranging from 35 to $150 \mathrm{~min}$ in duration. The short interval between the stimuli resulted in a facilitation of the second response, which was referred to as the paired-pulse facilitation (PPF) (Fig. 2C). We found that PPF was similar in control $(n=11)$ and lithium-treated $(n=9)$ rats (Fig. $2 D)$. The results suggest presynaptic glutamate release probability is unaltered after lithium treatment.
Lithium or VPA treatment attenuates surface expression and synaptic localization of GluR1/2 in cultured hippocampal neurons

The mechanisms underlying the effects of lithium or VPA on AMPA receptor synaptic localization were investigated using hippocampal neuronal cultures. The cultures were prepared from E18 embryos to yield a strictly neuronal population ( $~ 95 \%$; data not shown) and cultured for 8-10 d to establish synaptic neuronal connections.

Previous studies have shown a reduction in GluR1 on the membrane surface after lithium or VPA treatments (Du et al., 2004). Here, we wanted to determine surface GluR2 levels on hippocampal neurons after lithium or VPA treatment. Therapeutically relevant concentrations of lithium or VPA were applied to cultured hippocampal neurons, and surface GluR2 levels were determined by a biotinylation assay. Both lithium and VPA significantly attenuated GluR2 surface expression in a timedependent manner with maximum inhibitions of 24 and 39\%, respectively (Fig. $3 A, B$ ). The membranes used for GluR2 detection were stripped for Western blot of the neuronal surface protein marker pan-cadherin. Pan-cadherin remained unchanged after chronic treatment with lithium or VPA (Fig. 3C).

In addition, the cytosol marker C-Src was used as a control for the surface protein. C-Src presented in the total protein fraction $(20 \mu \mathrm{g})$ but was absent in the surface protein extracted from 20 $\mu \mathrm{g}$ of total protein (Fig. 3D). Surface GluR2 levels were significantly reduced in the $1.0 \mathrm{~mm}$ lithium- or VPA-treated groups (Fig. $3 A, B$ ). The reduction in surface GluR2 levels was not seen immediately but required prolonged exposure (at least $24 \mathrm{~h}$ ). This suggests that a chronic mechanism for drug-dependent synaptic plasticity is involved, rather than the mechanisms underlying the rapid activity-dependent regulation of surface GluR2 receptors. Surface GluR2 reduction was sustained up to $7 \mathrm{~d}$ (the longest treatment undertaken; data not shown).

To further investigate GluR2 receptors at synapses after lithium or VPA treatment, we determined synaptic GluR2 levels with double immunostaining of GluR2 and synapsin I. Synapsin I puncta were used as a crude indicator of synaptic specialization. After $4 \mathrm{~d}$ of treatment with lithium (1.0 mM) or VPA (1.0 mM), fluorescent intensities of GluR2 (red) and synapsin I (green) were determined from individual synapses. Each synapse on the longest dendrite ( $90 \mathrm{~mm}$ in length) of 11-13 neurons per treatment $(\sim 250-350$ synapses per condition) were counted for fluorescent intensities (Fig. 3E). GluR2 intensities were significantly reduced in lithium- and VPA-treated neurons, by 73.4 and $51.2 \%$, respectively, compared with those of controls (Fig. $3 F$ ). The synapsin I signal was also used as an internal control. The ratio of red/green fluorescence at each individual synapse was also significantly reduced after lithium or VPA treatment by 70.5 and $59.2 \%$, respectively (Fig. $3 G$ ); in contrast, the dendritic length for each group of neurons remained unchanged (Fig $3 H$ ). The data suggest that decreased surface expression of GluR2 does translate into changes in GluR2 synaptic expression after long-term (4 d) treatment with mood stabilizers.

Inhibition of GluR1 phosphorylation at the PKA site (S845) of the receptor is sufficient to regulate GluR1/2 tetramer membrane localization in vitro

Previous studies have shown that lithium or VPA specifically attenuates phosphorylation of GluR1 at its PKA site S845 (Du et al., 2003b, 2004). GluR1 phosphorylation is required for the insertion of GluR1/2 tetramers into neuronal membranes. However, phosphorylation of the CaMKII site, which is responsible 

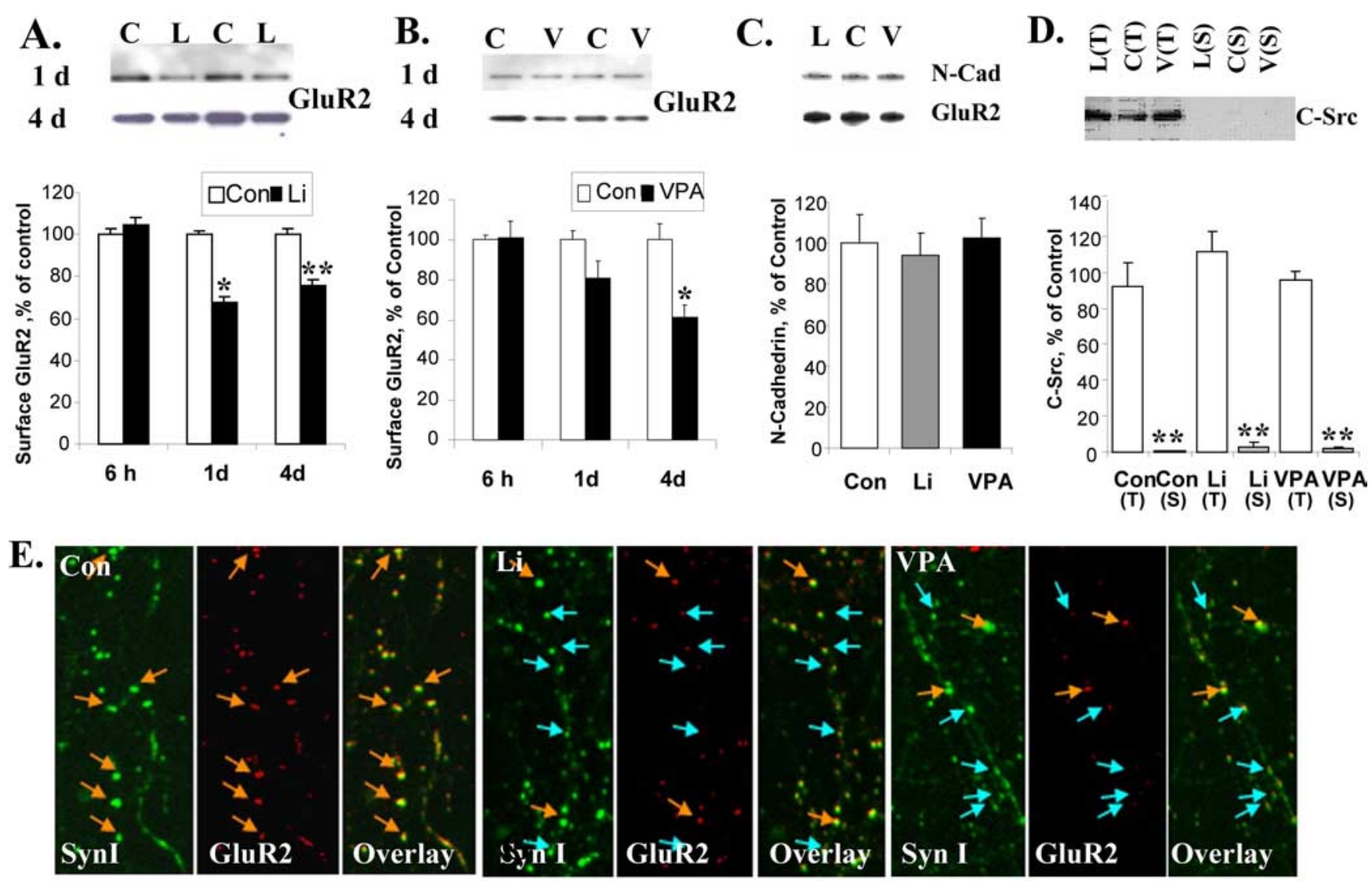

F.

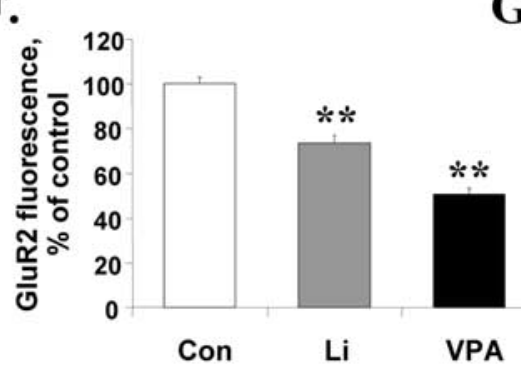

G.

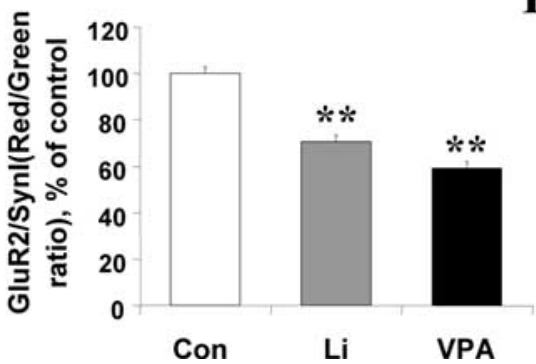

H.

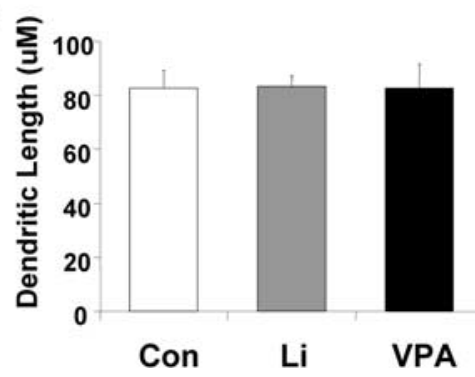

Figure 3. Surface and synaptic GluR2 levels in cultured hippocampal neurons are time-dependently decreased after treatment with lithium or VPA. Surface GluR2 levels were determined by biotinylation after treatment with lithium (L, Li; $1.0 \mathrm{~mm}$ ) or VPA (V; $1.0 \mathrm{~mm})$. Data were summarized from two to three independent experiments. For the immunostaining study, hippocampal neurons were double stained with anti-GluR2 (red) and anti-synapsin I (Synl; green) antibodies after lithium (1.0 mM) or VPA (1.0 mm) treatment for $4 \mathrm{~d}$. The GluR2-positive synapses are indicated with yellow arrows, and GluR2-negative synapses are indicated with blue arrows. Data were combined from two to three independent experiments. C/Con, Control. $A$, The effects of lithium (1.0 mm) on surface GluR2 after $6 \mathrm{~h}, 1 \mathrm{~d}$, or $4 \mathrm{~d}$ treatment ( $n=5-7$ for each condition; $1 \mathrm{~d}$ Con vs Li, ${ }^{*} p=0.011 ; 4 \mathrm{~d}$ Con vs Li, ${ }^{* *} p=0.001$; Student's $t$ test). $\boldsymbol{B}$, The effects of VPA (1.0 mm) on surface GluR2 after $6 \mathrm{~h}, 1 \mathrm{~d}$, or $4 \mathrm{~d}$ treatment ( $n=5-7 ; 4 \mathrm{~d}$ Con vs VPA, ${ }^{*} p=0.023$; Student's $t$ test). $C$, N-cadherin (N-Cad) remained unchanged in the surface protein fraction after lithium or VPA treatment ( $n=$ 6). $\boldsymbol{D},\left(-\right.$-Src, a cytosal marker, is absent in the surface (S) protein fraction and abundant in total protein (T) ( $n=3-6$; Student's t test, $\left.{ }^{* *} p<0.001\right)$. $E$, Double immunostaining of GluR2 and synapsin I indicated that GluR2 is attenuated at synapses. $\boldsymbol{F}$, Quantification of GluR2 (red) fluorescent intensity at the synapses ( $n=250-350$ synapses for each group; one-way AN0VA, $p<0.001$, Bonferroni's multiple comparison; Con vs Li, ${ }^{* *} p<0.001$; Con vs VPA, ${ }^{* *} p<0.001$ ). G, The GluR2 (red)/synapsin I (green) ratio at synapses of hippocampal neurons after lithium or VPA treatment ( $n=250-350$ synapses for each group; one-way ANOVA, $p<0.001$, Bonferroni's multiple comparison; Con vs Li, ${ }^{* *} p<0.001 ;$ Con vs VPA, ${ }^{* *} p<0.001$ ). $\boldsymbol{H}$, Equal dendrite lengths were used for quantification in each treatment condition. Error bars indicate $S E$.

for movement of GluR1/2 into synapses, remains unchanged after chronic lithium or VPA treatment (Du et al., 2003b, 2004). We hypothesized that the reduction in synaptic GluR2 would be associated with the attenuation of GluR1 phosphorylation at its PKA site.

To test this hypothesis, we designed a fusion peptide, TATS845, that specifically inhibits PKA-mediated phosphorylation of the Ser 845 residue of the GluR1 subunit of the AMPA receptor and takes advantage of the delivery potential of the TAT peptide from HIV (Cao et al., 2002). TAT-S845 peptide or a TAT-SCR peptide with a scrambled sequence was applied to hippocampal neurons at a concentration of $80 \mu \mathrm{M}$ for $2 \mathrm{~h}, 15 \mathrm{~h}$, or $3 \mathrm{~d}$. Western blot analysis with anti-phospho-GluR1 (S845) antibody showed that phosphorylation of GluR1 S845 was significantly reduced after $2 \mathrm{~h}$ of peptide treatment (Fig. 4A). This reduction in phospho-GluR1S845 was sustained for $3 \mathrm{~d}$ (Fig. $4 B$ ).

The membrane used for Western blot of anti-phosphoGluR1S845 antibody after $3 \mathrm{~d}$ of peptide treatment was stripped and reprobed with anti-GluR1S831 and anti-Synapsin I S9 (a PKA site) antibodies. The phospho-serine site on GluR1 S831 (phosphorylated by CAMKII) remained unchanged after $3 \mathrm{~d}$ of treatment with TAT-S845, TAT-Con peptides or control (Fig. 


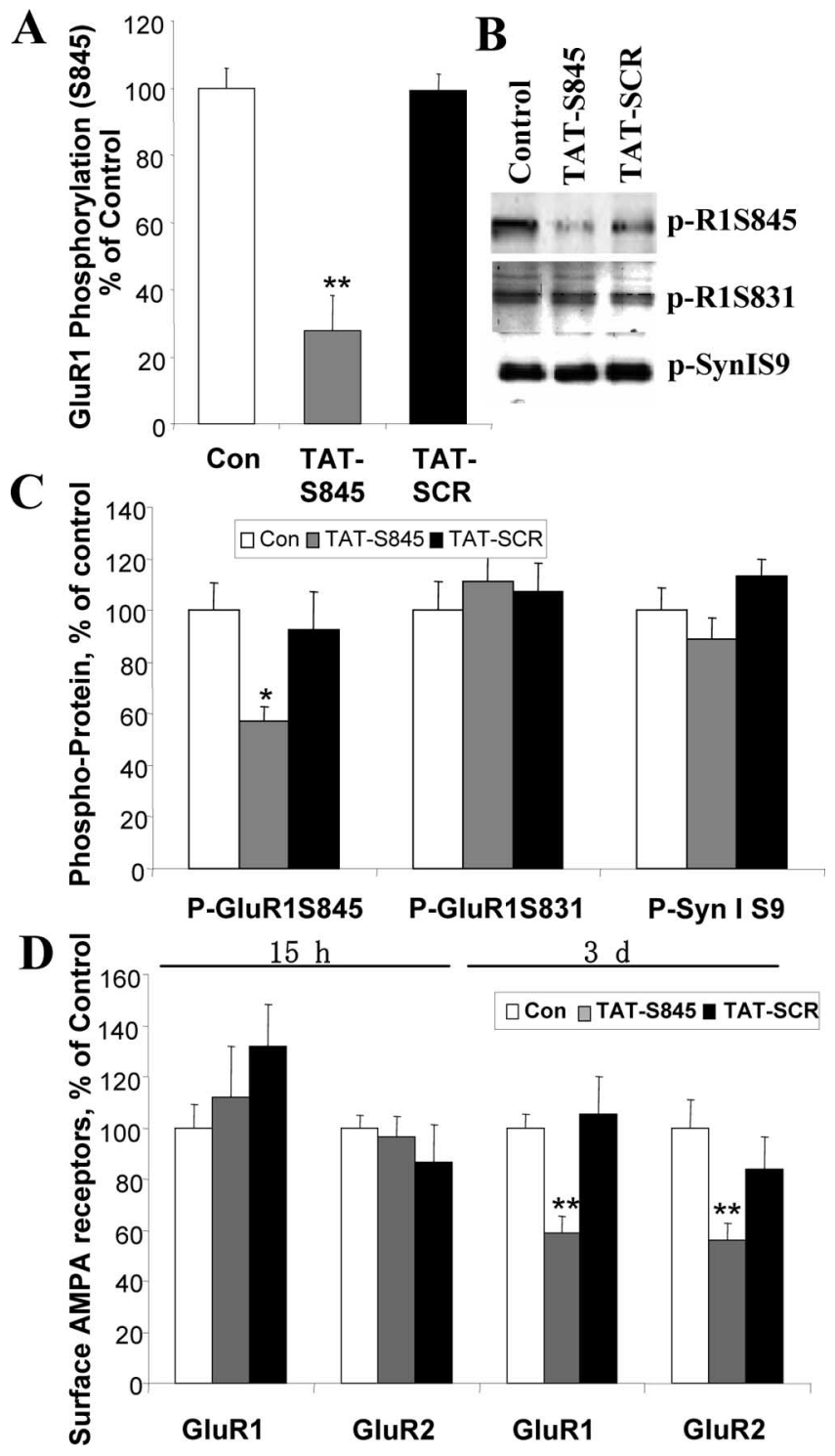

Figure 4. TAT-S845 peptide inhibits GluR1 phosphorylation of S845 on PKA site and surface expression of GluR1 and GluR2 in a time-dependent manner. Hippocampal neurons (10 $\mathrm{d}$ in vitro) were treated with peptide TAT-S845 or scrambled control (Con) peptide TAT-SCR ( $80 \mu \mathrm{m}$ ) for the times indicated. Data were combined from two to three independent experiments. $\boldsymbol{A}$, After $2 \mathrm{~h}$ treatment, phosphorylation of GluR1 at $S 845$ was significantly reduced $(n=18$; one-way ANOVA, $p<0.001$; Con vs TAT-S845, ${ }^{* *} p<0.001$; TAT-SCR vs TATS845, ${ }^{* *} p<$ 0.001). B, C, After $3 \mathrm{~d}$ of treatment, phospho-GluR1S845, phospho-GluR1S831, and phosphosynapsin I were determined (one-way ANOVA, ${ }^{*} p=0.0217 ; n=30$ ). $\boldsymbol{D}$, Surface GluR1 or GluR2 was determined by biotinylation assay after TAT-S845 and TAT-SCR treatment ( $n=38$; GluR1, one-way ANOVA, ${ }^{* *} p=0.0095$; GluR2, one-way ANOVA, $\left.{ }^{* *} p=0.0053\right)$. Error bars indicate SE.

$4 B, C)$. In addition, the phosphorylation of synapsin I on its PKA site serine 9 showed no significant change after treatment with the TAT-S845 peptide (Fig. $4 B, C$ ). To determine whether the peptide altered membrane localization of GluR1 or GluR2, cultured hippocampal neurons were treated with the peptide for $15 \mathrm{~h}$ or $3 \mathrm{~d}$. We found that membrane localization of both GluR1 and GluR2 remained unchanged after $15 \mathrm{~h}$ of treatment, although an inhibition of phosphorylation at the GluR1 S845 site started after $2 \mathrm{~h}$ of treatment. After $3 \mathrm{~d}$ of treatment with TATS845 peptide, both surface GluR1 and GluR2 were attenuated to 58.8 and $55.9 \%$, respectively (Fig. $4 D$ ), suggesting that attenuation of GluR1 S845 phosphorylation is sufficient to reduce GluR1/GluR2 surface expression.
Inhibition of GluR1 phosphorylation at the PKA site (S845) of the receptor is sufficient to regulate GluR1/2 synaptic localization in vivo

To further determine whether inhibition of GluR1S845 is sufficient to reduce synaptic GluR1/GluR2 in vivo, we injected mice intraperitoneally with TAT-S845 peptide and investigated its effects on GluR1 phosphorylation and GluR1/2 synaptic localization. We found that $5 \mathrm{mg}$ (but not $1 \mathrm{mg}$ ) of TAT-S845 peptide per $25 \mathrm{~g}$ mouse weight significantly reduced GluR1 phosphorylation at its PKA site $6 \mathrm{~h}$ after intraperitoneal injection (data not shown). Therefore, we chose $4 \mathrm{mg} / 25 \mathrm{~g}$ mouse/d as the injection dose and intraperitoneally injected the TAT-S845 and control peptide into the animals for $4 \mathrm{~d}$. Phosphorylation of GluR 1 at the S845 site in hippocampal homogenates was analyzed by Western blot analysis. S845 GluR1 levels were significantly attenuated to $56.2 \pm 12 \%$ in TAT-S845 peptide-treated animals compared with that of TAT-SCR control peptide-treated animals (100 $\pm 6.5 \%$; $n=4$; Student's $t$ test, $p=0.018$ ). Total GluR1 levels, which were determined by stripping of the membrane for phospho-GluR1 detection, remained unchanged (TAT-SCR: $100 \pm 1.6 \%, n=4$; TAT-S845: $103.5 \pm 21.2 \%, n=4)$. Levels of actin, which was used as a loading control, were unchanged (data not shown).

Synaptic GluR1/2 from synaptosomal fractions was also determined by Western blot analysis with anti-GluR1 and antiGluR2 antibodies. Synaptic GluR1 was attenuated in TAT-S845treated animals to $62.2 \pm 11.7 \%$ (TAT-SCR: $100 \pm 2.5 \%, n=4$; Student's $t$ test, $p=0.034$ ), and synaptic GluR2 was also reduced to $41.8 \pm 14 \%$ (TAT-SCR: $100 \pm 5.7 \%, n=4$; Student's $t$ test, $p=0.008)$, suggesting that attenuation of GluR1 phosphorylation at its PKA site is sufficient to mimic the effects of lithium or VPA on GluR1/2 receptor synaptic localization. NR1 levels at the synapse remained unchanged (TAT-SCR, $100 \pm 18.9 \%$; TATS845, $88.8 \pm 14.5 \% ; n=4$ for each group).

Hippocampal administration of the chemical AMPA antagonist GYKI 52466 or the TAT-S845 peptide inhibitor attenuates amphetamine-induced hyperactivity

Because lithium and VPA both regulate hippocampal synaptic GluR1/2 despite being highly dissimilar structurally, we sought to investigate the role of these receptors in mediating manic-like behaviors. The first behavior examined was amphetamineinduced hyperactivity. This test has been used as a model of mania, and lithium treatment has consistently been shown to inhibit amphetamine-induced hyperactivity (Poncelet et al., 1987; Takigawa et al., 1994; Beaulieu et al., 2004; Frey et al., 2006a,b; Shaldubina et al., 2007).

Rats undergoing continuous infusion $(0.25 \mu \mathrm{l} / \mathrm{min})$ of the noncompetitive AMPA receptor antagonist GYKI 52466 (50 $\mu \mathrm{M})$ or its aCSF vehicle control into the dentate gyrus of the hippocampus appeared healthy and exhibited normal motor coordination throughout the study. The two groups did not differ significantly in distances traveled during a $60 \mathrm{~min}$ open-field test (Fig. 5A). However, when challenged with a low dose of amphetamine $(1 \mathrm{mg} / \mathrm{kg})$ to induce a manic-like state, the AMPA receptor antagonist GYKI 52466 group exhibited a highly significant attenuation of amphetamine-induced hyperactivity compared with the control group (unpaired Student's $t$ test; $t_{(12)}=4.272$; $p<0.0001$ ) (Fig. 5B). In addition, there were significant differences between the two groups during this baseline period in distance traveled after GYKI 52466 treatment (unpaired $t$ test; $t_{(12)}$ $=2.806 ; p=0.0053$ ) (Fig. $5 B$ ). The difference in distances traveled between the two groups was also much greater during the 

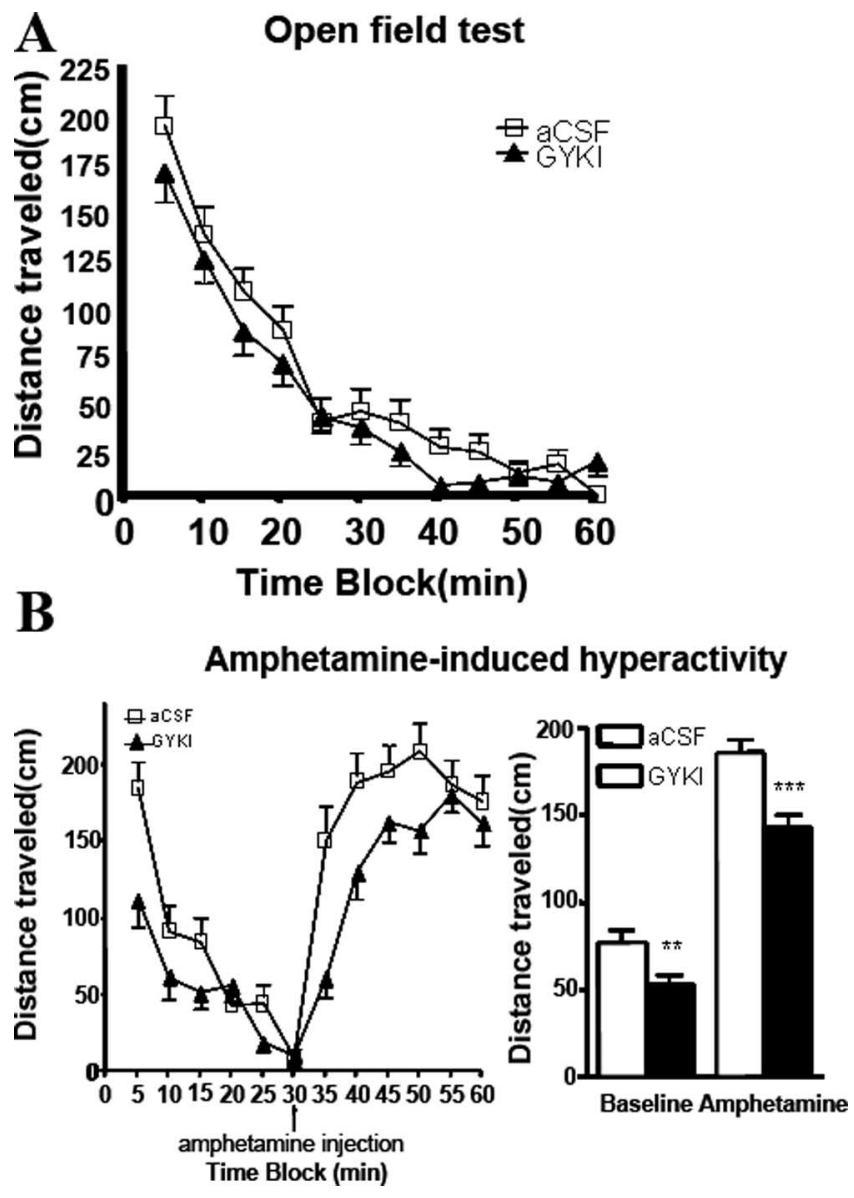

Figure 5. Hippocampal infusion of AMPA receptor antagonist GYKI 52466 affects manic-like behaviors. Rats were implanted bilaterally with cannula systems for continuous delivery of either GYKI $52466(50 \mu \mathrm{M})$ or vehicle (aCSF) control to the hippocampus. A, Open-field test. Eight days after surgery, rats were run in activity boxes for 60 min sessions. Distances traveled were scored by an automated tracking system. No significant differences were detected between treatment groups and controls for the $60 \mathrm{~min}$ time blocks or any of the constituent $5 \mathrm{~min}$ time blocks ( $n=6 ; p>0.05$, unpaired $t$ test). $\boldsymbol{B}$, Amphetamine-induced hyperactivity. Ten days after surgery, rats were run in activity boxes for 30 min immediately followed by an intraperitoneal injection of $1 \mathrm{mg} / \mathrm{kg}$ amphetamine and placed back in the activity boxes for another $30 \mathrm{~min}$. Distances traveled were scored as in the open-field test. Significant differences in baseline and amphetamine-challenged distances traveled between the control and GYKI 52466 groups were detected ( $n=6$; baseline: $t=2.806,{ }^{* *} p=0.0053$; amphetamine: $t=$ $4.272,{ }^{* * *} p=0.0001$; unpaired $t$ test). Error bars indicate SE.

amphetamine challenge than during the baseline period (Fig. $5 A)$.

Because TAT-S845 peptide, a peptide that inhibits GluR1 phosphorylation at its PKA site, was able to mimic the biochemical effects of lithium or VPA and attenuate synaptic localization of AMPA GluR1/2, we decided to confirm the involvement of GluR1/2 in hippocampus in amphetamine-induced hyperactivity using TAT-S845 peptide. First, we determined the effect of the peptide on GluR1 S845 phosphorylation by immunohistochemistry after a $14 \mathrm{~d}$ mini-pump infusion in the hippocampal dentate gyrus region (Fig. 6). We found that phospho-GluR1S845positive neurons were significantly attenuated in neurons in TAT-S845-treated CA1 and in dentate gyrus regions but not in the neurons in CA3 (Fig. 6).

Rats underwent continuous infusion $(0.25 \mu \mathrm{l} / \mathrm{min})$ of TATS845 peptide $(160 \mu \mathrm{M})$, TAT-SCR peptide $(160 \mu \mathrm{M})$, or an aCSF vehicle control $(160 \mu \mathrm{M})$ into the dentate gyrus of the hippocampus. We selected a dosage twice that used in the hippocampal culture experiments to compensate for its potentially less efficient in vivo peptide delivery and/or cellular transfection. The three groups did not differ significantly in distances traveled in the 60 min open-field test (Fig. 7A). There were no significant differences among the groups in distance traveled during the baseline period of the amphetamine challenge test (Fig. 7); however, there was a highly significant difference among the groups in distance traveled during the $30 \mathrm{~min}$ amphetamine challenge (one-way ANOVA; $\left.F_{(2,537)}=11.057 ; p<0.0001\right)$. The distance traveled by the TAT-S845 group was significantly attenuated relative to either the control peptide TAT-SCR group (Tukey's post hoc tests, $p<0.001$ ) or the aCSF control group (Tukey's post hoc tests, $p<0.01$ ). Our data suggest that hippocampal GluR1/2 plays a key role in the hyperactivity induced by amphetamine (Fig. 7B). There were no differences in distances traveled between the two control groups (Fig. $7 B$ ), indicating that the TAT-SCR peptide had no behavioral effect.

\section{Discussion}

In this study, we conducted a series of experiments that suggest that hippocampal AMPA GluR1/2 receptor subunit-specific trafficking may play an important role in the pathophysiology and treatment of manic-like behaviors. First, we found that both of the structurally dissimilar antimanic agents lithium and VPA downregulated AMPA GluR1/2 synaptic expression in the hippocampus after chronic treatment with therapeutically relevant concentrations, as assessed both in vitro and in vivo. Second, we confirmed that this biochemical observation is functionally significant by conducting an electrophysiological study showing that the AMPA/NMDA ratio is decreased in hippocampal CA1 neurons in animals chronically treated with lithium. Third, we found that TAT-S845, a peptide that inhibits GluR1 (S845) phosphorylation at its PKA site, was able to mimic the effects of lithium or VPA in attenuating both GluR1 and GluR2 surface expression in vitro and synaptic localization of GluR1 and GluR2 in the hippocampus in vivo. Fourth, we found that hippocampal dentate gyrus regional delivery of the AMPA-specific inhibitor GYKI 52466 and TAT-S845 peptide attenuated amphetamineinduced hyperactivity, suggesting that the hippocampal GluR1/2 receptors play an important role in amphetamine-induced manic behavior. Together, these data support the hypothesis that the effects of chronic treatment with lithium or VPA converge to regulate phosphorylation of the PKA site of GluR1 and thereby attenuate synaptic GluR1/2 levels; furthermore, this attenuation of GluR1/2 at synapses in vivo contributes to the antimanic effects of lithium or VPA.

Regulation of AMPA receptor trafficking by antimanic agents is a therapeutically relevant biological effect

Because chronic administration of antimanic agents induces numerous biochemical effects, our laboratory (Manji and Lenox, 1999, 2000) and others (Coyle and Duman, 2003) have established several criteria that biological effects should meet to maximize their potential therapeutic efficacy. Our paradigm has five main components that this series of experiments fulfills. First, the effect of structurally different antimanic agents (such as lithium or VPA) had a common effect on GluR1/2 synaptic localization. Second, the attenuation of synaptic GluR1/2 by lithium or VPA occurred in the hippocampus, which is a brain region known to involve neuronal circuits critical for affective disorders (Brambilla et al., 2002; Velakoulis et al., 2006; Atmaca et al., 2007). Third, the effect of lithium or VPA on synaptic GluR1/2 occurred at therapeutically relevant concentrations both in vivo and in 

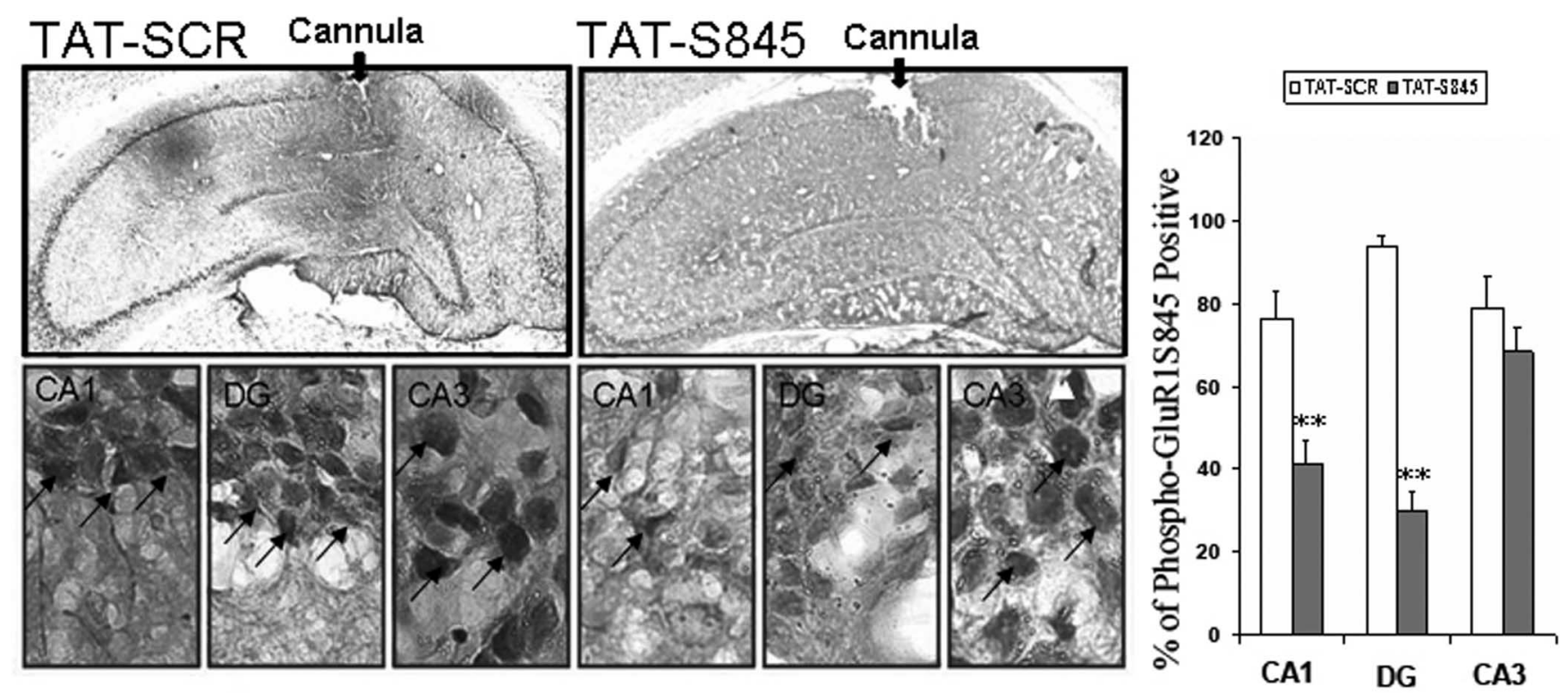

Figure 6. Hippocampus infusion of TAT-S845 peptide significantly attenuates GluR1 8845 phosphorylation in CA1 and dentate gyrus (DG). Rats were implanted bilaterally with cannula systems for continuous delivery of either TAT-S845 peptide or control peptide TAT-SCR. After behavioral tests were completed, brains were fixed, and brain sections were immunostained with anti-phosphoGluR1S845 antibody. GluRS845-positive cells are quantified in three brain regions in the hippocampus (CA1, CA3, and DG), as described in Materials and Methods (CA1 region, Student's t test, ${ }^{* *} p=$ $0.0061 ; D G$, Student's $t$ test, ${ }^{* *} p=0.0057 ; n=4$ animals for each group). Error bars indicate SE.

vitro. Fourth, similar to clinically therapeutic effects, the changes in GluR1/2 activity were observed only after chronic, not acute, administration of lithium or VPA; furthermore, their combined administration had an additive effect (data not shown). Fifth, the effects were specific to antimanic agents; pro-manic agents (antidepressants, psychostimulants) (Snyder et al., 2000; Edwards et al., 2007) produced opposite effects. Finally, we used electrophysiological studies to confirm that the biochemical observation that lithium decreased synaptic GluR1/2 in the hippocampus had a functional significance; we discerned that the AMPA/NMDA ratio is decreased in CA1 regions in lithium-treated animals.

Our previous work had established that synaptic NR1 levels do not change after lithium treatment in vivo (Du et al., 2004). Thus, the synaptic GluR1/2 reduction in this study would be expected to contribute mainly to the reduction in AMPA/NMDA ratio. The regulation of glutamatergic synaptic transmission in the CA1 region by lithium most likely occurs through a postsynaptic, not presynaptic, mechanism because no difference was found in the CA1 region between the lithium-treated and control groups in the PPF. For electrophysiological studies, we used hippocampal slices from 8- to 9-week-old (56-63 d) rats instead of 11- to 12-week-old (77-84 d) rats in biochemical studies, because the neurons in hippocampal slices have a better survival rate for electrophysiological recording. Rats reach sexual maturity at 38-50 d (Gabriel et al., 1992; Quinn, 2005) and become adults in $90 \mathrm{~d}$ (Gabriel et al., 1992; Zemunik et al., 2003). Therefore, our work measures the effects of lithium on synaptic plasticity at a similar adolescent stage (6-12 weeks) for both electrophysiology and biochemical studies (Zemunik et al., 2003).

\section{The effects of chronic lithium or VPA converge to attenuate synaptic localization of GluR1/2 tetramers via dephosphorylation of the PKA site of GluR1 receptors}

In this study, we investigated the detailed mechanism whereby antimanic agents modulate AMPA receptor localization. In cultured hippocampal neurons, lithium or VPA attenuated surface and synaptic GluR1/2 expression after chronic treatment (Du et al., 2004). In addition, inhibition of GluR1 phosphorylation by a specific peptide, TAT-S845, was sufficient to attenuate GluR1/2 surface expression in vitro and synaptic expression in vivo (Fig. 4).

Subunit-specific functions governing the synaptic delivery of AMPA receptors during formation of LTP have been studied extensively by elegant electrophysiological assays in hippocampal slice cultures (Hayashi et al., 2000; Zhu et al., 2000; Shi et al., 2001 ) and corroborated by cellular biological studies in dissociated cultures (Sheng and Lee, 2001; Passafaro et al., 2003). In activity-dependent regulation of subunit-specific AMPA receptor trafficking, GluR1 is the critical subunit that "drives" AMPA receptors to the surface and to synapses in response to various stimuli (Fu et al., 2004). Specifically, activity-dependent movement into synapses are governed by two steps: (1) insertion of GluR1/2 onto the neuronal surface is governed by phosphorylation of GluR1 on its PKA site (GluR1 S845); and (2) GluR1/2 movement into synapses is regulated by the activation of CaMKII and mitogen-activated protein kinase (Hayashi et al., 2000; Lee et al., 2000). In heteromeric receptors, GluR1 acts "dominantly" over GluR2 (Shi et al., 2001). Thus, in the hippocampus, it is believed that GluR1/2 heteromers are quickly delivered to synapses (Du et al., 2004) during activity-dependent synaptic potentiation, such as LTP.

In contrast to activity-dependent synaptic delivery of AMPA receptors into synapses, little is known about the druginduced mechanisms of specific subunits of AMPA receptor trafficking at synapses. The results of this study suggest an unexpected model: that the antimanic agents lithium and VPA downregulate GluR1/2 by inhibiting phosphorylation of GluR1 at its PKA site using a drug-specific "chronic mechanism" (Du et al., 2004, 2006). Our previous studies found that phosphorylation of GluR1 at the PKA site (S845) is significantly attenuated after treatment with lithium or VPA; however, phosphorylation of GluR1 at the CaMKII/PKC site remains unchanged, suggesting that lithium or VPA regulates GluR1 insertion but not fast movement into the synapses ( Du 
A

\section{Open field test}

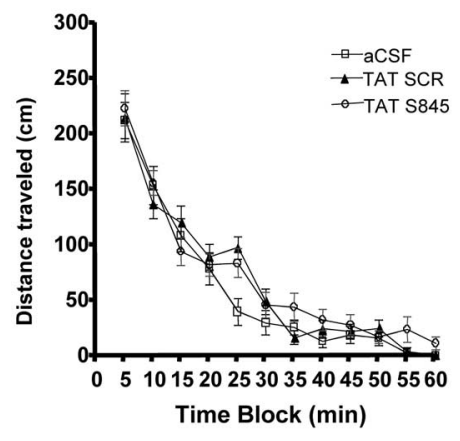

B

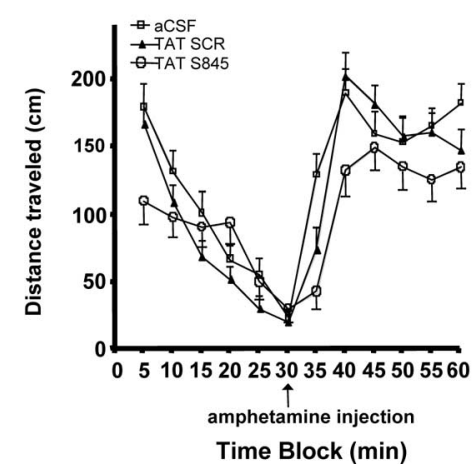

Figure 7. Hippocampal infusion of AMPA receptor-specific TAT-S845 peptide affects maniclike behaviors. Rats were implanted bilaterally with cannula systems for continuous delivery of TAT-S845 peptide, control peptide TAT-SCR, or vehicle (aCSF) control. A, Open-field test. Eight days after surgery, rats were run in activity boxes for 60 min sessions. Distances traveled were scored by an automated tracking system. No significant differences were detected between treatment groups and controls for the 60 min time blocks or any of the constituent 5 min time blocks $\left(n=6 ; F_{(2,1077)}=1.816 ; p=0.1632\right.$, one-way ANOVA). $\boldsymbol{B}$, Amphetamine-induced hyperactivity. Ten days after surgery, rats were run in activity boxes for 30 min immediately followed by an intraperitoneal injection of $1 \mathrm{mg} / \mathrm{kg}$ amphetamine and placed back in the activity boxes for another $30 \mathrm{~min}$. Distances traveled were scored as in the open-field test. One-way ANOVA detected no significant baseline differences in distances traveled among the aCSF, TATSCR peptide, and the TAT-S845 peptide groups. Significant differences in distances traveled among the groups for the amphetamine challenge test were detected $\left(n=6 ; F_{(2,537)}=11.06\right.$; $p<0.0001$, one-way ANOVA; aCSF vs TAT-S845 groups, $\left.{ }^{* *} p<0.01\right)$; TAT-SCR peptide vs TAT-S845 peptide groups, ${ }^{* * *} p<0.001$; aCSF vs TAT-SCR peptide groups, $p>0.05$; Tukey's post hoc tests). Error bars indicate SE.

et al., 2004). The present study found that GluR2, but not GluR3, is attenuated at synapses in vivo and in vitro in a chronic manner. GluR1/2 heteromers are assembled in the endoplasmic reticulum, and the assembled hetero-tetramers remain as a functional unit while being transported into dendrites by vesicles (Vandenberghe et al., 2005). It is now well established that regulation of synaptic GluR1/2 trafficking is a complex, multifaceted process. We propose that the attenuation of synaptic GluR1 by antimanic agents is a two-step process involving (1) attenuation of surface GluR1/GluR2, governed by phosphorylation of GluR1 on the PKA site (GluRS845), followed by (2) a gradual reduction in synaptic GluR1/2 receptors. Consistent with the effects observed in the present study, previous in vivo and in vitro studies show that chronic lithium or VPA treatments attenuate adenylyl cyclase activity via distinct mechanisms (Du et al., 2003b, 2004). Previous work suggests a significant delay between attenuation of GluR1 surface expression and a decrease in GluR1 at func- tional synapses in cultured cortical neurons (Wolf et al., 2003). This model is also confirmed by the in vivo study, in which TAT-S845 peptide attenuated synaptic GluR1/2. These findings are compatible with the delayed onset of the antimanic effects of lithium or VPA, which can take several days or weeks to manifest.

Inhibition of synaptic AMPA receptor activity by GYKI 52466 or TAT-S845 in hippocampus attenuates amphetamineinduced manic behavior

Previous studies have shown that lithium has an antimanic effect against amphetamine-induced hyperactivity (Poncelet et al., 1987; Takigawa et al., 1994; Beaulieu et al., 2004; Frey et al., 2006a,b; Shaldubina et al., 2007). In this study, we showed that three different experimental paradigms (treatment with lithium, treatment with AMPA antagonist GYKI 52466 infusion, or treatment with GluR1S845 phosphorylation inhibitory peptide TATS845 infusion) display a common effect; namely, they all attenuate hippocampal synaptic AMPA receptors and reduce amphetamine-induced hyperactivity. In our study, we observed an inhibition by GYKI 52466 on basal locomotor activity before the amphetamine injection (Fig. 5). After amphetamine treatment, the GYKI 52466 inhibited local motion to a greater extent ( $\sim 72 \%$ more) than the inhibition in basal local motor activity. To further investigate amphetamine-induced hyperactivity, we therefore followed up with TAT-S845, which is a more specific inhibitor for GluR1 to mimic the effect of lithium. It is worth mentioning that the peptide TAT-S845 did not have any effects on basal locomotor activity. These data suggest that AMPA receptor activity plays an important role in the hyperactivity induced by amphetamine. Notably, a number of pharmacological studies also suggest that attenuating AMPA/kainate receptors results in antimanic-like effects (Einat and Manji, 2006).

Recent functional brain imaging studies have identified critical neural circuits involving the prefrontal cortical regions, anterior cingulate, hippocampus, thalamus, basal ganglia, and amygdala that modulate emotional behavior and that are disturbed in primary and secondary mood disorders (Carlson et al., 2006). Accumulating evidence suggests an association between the hippocampal region and bipolar disorder (Brambilla et al., 2002; Velakoulis et al., 2006; Atmaca et al., 2007). For instance, functional MRI has identified hippocampal morphological abnormalities in bipolar patients (Brambilla et al., 2002; Velakoulis et al., 2006; Atmaca et al., 2007). In addition, a recent study showed that, in the hippocampal CA1 region, the cell size of pyramidal neurons was significantly reduced in bipolar disorder patients (Liu et al., 2007). It has also been shown that dorsal hippocampal lesions are involved in cocaine-induced conditioned place preference (Meyers et al., 2003). Notably, the role of PKA in AMPA receptor trafficking in the CA1 region of the hippocampus is well characterized through studies of learning and memory. Although the specific role of each brain region in mood disorders remains unclear, our study suggests that the dorsal hippocampus is involved in amphetamine-induced manic-like behavior and that the hippocampus may contribute to regulation of the reward pathway (Hyman et al., 2006).

In conclusion, the present work provides evidence that hippocampal GluR1/2 plays an important role in the pathophysiology and treatment of manic-like behavior. Our results also provide new technical information about the distinct machinery that influences drug-specific regulation of GluR1/2. Given the links between the GluR1/2 subunit and manic-like behavior induced by psychostimulants, these studies may also ultimately provide 
novel targets for the development of new therapeutics for bipolar disorder.

\section{References}

Atmaca M, Yildirim H, Ozdemir H, Ogur E, Tezcan E (2007) Hippocampal $1 \mathrm{H}$ MRS in patients with bipolar disorder taking valproate versus valproate plus quetiapine. Psychol Med 37:121-129.

Banke TG, Bowie D, Lee H, Huganir RL, Schousboe A, Traynelis SF (2000) Control of GluR1 AMPA receptor function by cAMP-dependent protein kinase. J Neurosci 20:89-102.

Barria A, Derkach V, Soderling T (1997) Identification of the Ca2+/ calmodulin-dependent protein kinase II regulatory phosphorylation site in the alpha-amino-3-hydroxyl-5-methyl-4-isoxazole-propionate-type glutamate receptor. J Biol Chem 272:32727-32730.

Beaulieu JM, Sotnikova TD, Yao WD, Kockeritz L, Woodgett JR, Gainetdinov RR, Caron MG (2004) Lithium antagonizes dopamine-dependent behaviors mediated by an AKT/glycogen synthase kinase 3 signaling cascade. Proc Natl Acad Sci USA 101:5099-5104.

Brambilla P, Barale F, Caverzasi E, Soares JC (2002) Anatomical MRI findings in mood and anxiety disorders. Epidemiol Psichiatr Soc 11:88-99.

Brebner K, Wong TP, Liu L, Liu Y, Campsall P, Gray S, Phelps L, Phillips AG, Wang YT (2005) Nucleus accumbens long-term depression and the expression of behavioral sensitization. Science 310:1340-1343.

Cao G, Pei W, Ge H, Liang Q, Luo Y, Sharp FR, Lu A, Ran R, Graham SH, Chen J (2002) In vivo delivery of a Bcl-xL fusion protein containing the TAT protein transduction domain protects against ischemic brain injury and neuronal apoptosis. J Neurosci 22:5423-5431.

Carlezon Jr WA, Nestler EJ (2002) Elevated levels of GluR1 in the midbrain: a trigger for sensitization to drugs of abuse? Trends Neurosci 25:610-615.

Carlson PJ, Singh JB, Zarate Jr CA, Drevets WC, Manji HK (2006) Neural circuitry and neuroplasticity in mood disorders: insights for novel therapeutic targets. NeuroRx 3:22-41.

Chao SZ, Ariano MA, Peterson DA, Wolf ME (2002) D1 dopamine receptor stimulation increases GluR1 surface expression in nucleus accumbens neurons. J Neurochem 83:704-712.

Coyle JT, Duman RS (2003) Finding the intracellular signaling pathways affected by mood disorder treatments. Neuron 38:157-160.

Derkach V, Barria A, Soderling TR (1999) Ca2+/calmodulin-kinase II enhances channel conductance of alpha-amino-3-hydroxy-5-methyl-4isoxazolepropionate type glutamate receptors. Proc Natl Acad Sci USA 96:3269-3274.

Drevets WC (2001) Neuroimaging and neuropathological studies of depression: implications for the cognitive-emotional features of mood disorders. Curr Opin Neurobiol 11:240-249.

Du J, Feng L, Yang F, Lu B (2000) Activity- and Ca(2+)-dependent modulation of surface expression of brain-derived neurotrophic factor receptors in hippocampal neurons. J Cell Biol 150:1423-1434.

Du J, Gould DT, Manji HK (2003a) Neurotrophic signaling in mood disorders. New York: Wiley.

Du J, Gray NA, Falke C, Yuan P, Szabo S, Manji HK (2003b) Structurally dissimilar antimanic agents modulate synaptic plasticity by regulating AMPA glutamate receptor subunit GluR1 synaptic expression. Ann NY Acad Sci 1003:378-380.

Du J, Gray NA, Falke CA, Chen W, Yuan P, Szabo ST, Einat H, Manji HK (2004) Modulation of synaptic plasticity by antimanic agents: the role of AMPA glutamate receptor subunit 1 synaptic expression. J Neurosci 24:6578-6589.

Du J, Suzuki K, Wei Y, Wang Y, Blumenthal R, Chen Z, Falke C, Zarate Jr CA, Manji HK (2006) The anticonvulsants lamotrigine, riluzole, and valproate differentially regulate AMPA receptor membrane localization: relationship to clinical effects in mood disorders. Neuropsychopharmacology 32:793-802.

Edwards S, Graham DL, Bachtell RK, Self DW (2007) Region-specific tolerance to cocaine-regulated cAMP-dependent protein phosphorylation following chronic self-administration. Eur J Neurosci 25:2201-2213.

Einat H, Manji HK (2006) Cellular plasticity cascades: genes-to-behavior pathways in animal models of bipolar disorder. Biol Psychiatry 59:1160-1171.

Esteban JA, Shi SH, Wilson C, Nuriya M, Huganir RL, Malinow R (2003) PKA phosphorylation of AMPA receptor subunits controls synaptic trafficking underlying plasticity. Nat Neurosci 6:136-143.

Frey BN, Andreazza AC, Rosa AR, Martins MR, Valvassori SS, Reus GZ,
Hatch JP, Quevedo J, Kapczinski F (2006a) Lithium increases nerve growth factor levels in the rat hippocampus in an animal model of mania. Behav Pharmacol 17:311-318.

Frey BN, Valvassori SS, Reus GZ, Martins MR, Petronilho FC, Bardini K, Dal-Pizzol F, Kapczinski F, Quevedo J (2006b) Effects of lithium and valproate on amphetamine-induced oxidative stress generation in an animal model of mania. J Psychiatry Neurosci 31:326-332.

Fu XZ, Zhang QG, Meng FJ, Zhang GY (2004) NMDA receptor-mediated immediate Ser831 phosphorylation of GluR1 through CaMKIIalpha in rat hippocampus during early global ischemia. Neurosci Res 48:85-91.

Gabriel SM, Roncancio JR, Ruiz NS (1992) Growth hormone pulsatility and the endocrine milieu during sexual maturation in male and female rats. Neuroendocrinology 56:619-625.

Goodwin FK, Jamison KR (2007) Manic-depressive illness: bipolar and recurrent unipolar disorders, Ed 2. New York: Oxford UP.

Hayashi Y, Shi SH, Esteban JA, Piccini A, Poncer JC, Malinow R (2000) Driving AMPA receptors into synapses by LTP and CaMKII: requirement for GluR1 and PDZ domain interaction. Science 287:2262-2267.

Hyman SE, Malenka RC, Nestler EJ (2006) Neural mechanisms of addiction: the role of reward-related learning and memory. Annu Rev Neurosci 29:565-598.

Judd LL, Akiskal HS (2003) The prevalence and disability of bipolar spectrum disorders in the US population: re-analysis of the ECA database taking into account subthreshold cases. J Affect Disord 73:123-131.

Lee HK, Barbarosie M, Kameyama K, Bear MF, Huganir RL (2000) Regulation of distinct AMPA receptor phosphorylation sites during bidirectional synaptic plasticity. Nature 405:955-959.

Liu L, Schulz SC, Lee S, Reutiman TJ, Fatemi SH (2007) Hippocampal CA1 pyramidal cell size is reduced in bipolar disorder. Cell Mol Neurobiol 27:351-358.

Loza B, Krolicki L, Papierski K, Mazurek I, Mosiolek A, Kokoszka A, Andrysiak R (2005) Psychophysiological analysis of bipolar disorder treatment with functional magnetic resonance imaging (fMRI), spectroscopic $(1 \mathrm{H}-$ MRS) and volumetric MRI assessment of CNS: report of three cases. Psychiatr Pol 39:1231-1236.

Malinow R (2003) AMPA receptor trafficking and long-term potentiation. Philos Trans R Soc Lond B Biol Sci 358:707-714.

Mammen AL, Kameyama K, Roche KW, Huganir RL (1997) Phosphorylation of the alpha-amino-3-hydroxy-5-methylisoxazole4-propionic acid receptor GluR1 subunit by calcium/calmodulin-dependent kinase II. J Biol Chem 272:32528-32533.

Manji HK, Lenox RH (1999) Ziskind-Somerfeld Research Award. Protein kinase $\mathrm{C}$ signaling in the brain: molecular transduction of mood stabilization in the treatment of manic-depressive illness. Biol Psychiatry 46:1328-1351.

Manji HK, Lenox RH (2000) The nature of bipolar disorder. J Clin Psychiatry 61 [Supp 13]:42-57.

Manji HK, Drevets WC, Charney DS (2001) The cellular neurobiology of depression. Nat Med 7:541-547.

Meyers RA, Zavala AR, Neisewander JL (2003) Dorsal, but not ventral, hippocampal lesions disrupt cocaine place conditioning. NeuroReport 14:2127-2131.

Nestler EJ, Carlezon Jr WA (2006) The mesolimbic dopamine reward circuit in depression. Biol Psychiatry 59:1151-1159.

Nestler EJ, Barrot M, DiLeone RJ, Eisch AJ, Gold SJ, Monteggia LM (2002) Neurobiology of depression. Neuron 34:13-25.

Passafaro M, Nakagawa T, Sala C, Sheng M (2003) Induction of dendritic spines by an extracellular domain of AMPA receptor subunit GluR2. Nature 424:677-681.

Peineau S, Taghibiglou C, Bradley C, Wong TP, Liu L, Lu J, Lo E, Wu D, Saule E, Bouschet T, Matthews P, Isaac JT, Bortolotto ZA, Y.T. W, Collingridge GL (2007) LTP inhibits LTD in the hippocampus via regulation of GSK3beta. Neuron 53:703-717.

Poncelet M, Dangoumau L, Soubrie P, Simon P (1987) Effects of neuroleptic drugs, clonidine and lithium on the expression of conditioned behavioral excitation in rats. Psychopharmacology (Berl) 92:393-397.

Pozzo-Miller LD, Gottschalk W, Zhang L, McDermott K, Du J, Gopalakrishnan R, Oho C, Sheng ZH, Lu B (1999) Impairments in high-frequency transmission, synaptic vesicle docking, and synaptic protein distribution in the hippocampus of BDNF knockout mice. J Neurosci 19:4972-4983.

Prien RF, Klett CJ, Caffey Jr EM (1973) Lithium carbonate and imipramine 
in prevention of affective episodes. A comparison in recurrent affective illness. Arch Gen Psychiatry 29:420-425.

Prien RF, Kupfer DJ, Mansky PA, Small JG, Tuason VB, Voss CB, Johnson WE (1984) Drug therapy in the prevention of recurrences in unipolar and bipolar affective disorders. Report of the NIMH Collaborative Study Group comparing lithium carbonate, imipramine, and a lithium carbonate-imipramine combination. Arch Gen Psychiatry 41:1096-1104.

Quinn R (2005) Comparing rat's to human's age: how old is my rat in people years? Nutrition 21:775-777.

Roche KW, O’Brien RJ, Mammen AL, Bernhardt J, Huganir RL (1996) Characterization of multiple phosphorylation sites on the AMPA receptor GluR1 subunit. Neuron 16:1179-1188.

Self DW (2002) Where's the excitement in psychostimulant sensitization? Neuropsychopharmacology 26:14-17.

Shaldubina A, Buccafusca R, Johanson RA, Agam G, Belmaker RH, Berry GT, Bersudsky Y (2007) Behavioural phenotyping of sodium-myo-inositol cotransporter heterozygous knockout mice with reduced brain inositol. Genes Brain Behav 6:253-259.

Sheng M, Lee SH (2001) AMPA receptor trafficking and the control of synaptic transmission. Cell 105:825-828.

Shi S, Hayashi Y, Esteban JA, Malinow R (2001) Subunit-specific rules governing AMPA receptor trafficking to synapses in hippocampal pyramidal neurons. Cell 105:331-343.

Snyder GL, Allen PB, Fienberg AA, Valle CG, Huganir RL, Nairn AC, Greengard P (2000) Regulation of phosphorylation of the GluR1 AMPA receptor in the neostriatum by dopamine and psychostimulants in vivo. J Neurosci 20:4480-4488.

Takigawa M, Fukuzako H, Ueyama K, Tominaga H (1994) Intracranial self- stimulation and locomotor traces as indicators for evaluating and developing antipsychotic drugs. Jpn J Psychiatry Neurol 48:127-132.

Vandenberghe W, Nicoll RA, Bredt DS (2005) Interaction with the unfolded protein response reveals a role for stargazin in biosynthetic AMPA receptor transport. J Neurosci 25:1095-1102.

Velakoulis D, Wood SJ, Wong MT, McGorry PD, Yung A, Phillips L, Smith D, Brewer W, Proffitt T, Desmond P, Pantelis C (2006) Hippocampal and amygdala volumes according to psychosis stage and diagnosis: a magnetic resonance imaging study of chronic schizophrenia, first-episode psychosis, and ultra-high-risk individuals. Arch Gen Psychiatry 63:139-149.

Wenthold RJ, Petralia RS, Blahos II J, Niedzielski AS (1996) Evidence for multiple AMPA receptor complexes in hippocampal CA1/CA2 neurons. J Neurosci 16:1982-1989.

Wolf ME, Mangiavacchi S, Sun X (2003) Mechanisims by which dopmine receptors may influence synaptic plasticity. Ann NY Acad Sci 1003:241-249.

Wu LJ, Xu H, Ren M, Cao X, Zhuo M (2007) Pharmacological isolation of postsynaptic currents mediated by NR2A- and NR2B-containing NMDA receptors in the anterior cingulate cortex. Mol Pain 3:11.

Young LT (2007) Is bipolar disorder a mitochondrial disease? J Psychiatry Neurosci 32:160-161.

Yuan P, Chen G, Manji HK (1999) Lithium activates the c-Jun NH2terminal kinases in vitro and in the CNS in vivo. J Neurochem 73:2299-2309.

Zemunik T, Peruzovic M, Capkun V, Milkovic K (2003) Behavioral characteristics of the offspring of adolescent rats. Braz J Med Biol Res 36:465-475.

Zhu JJ, Esteban JA, Hayashi Y, Malinow R (2000) Postnatal synaptic potentiation: delivery of GluR4-containing AMPA receptors by spontaneous activity. Nat Neurosci 3:1098-1106. 